\title{
KILKA UWAG NA TEMAT PRAKTYK MAGICZNYCH CHRZEŚCIJAN W PÓŹNOANTYCZNYCH KOŚCIELNYCH TEKSTACH NORMATYWNYCH
}

Praktyki, szeroko określane jako magiczne, stanowiły nieodłączny element życia codziennego w świecie starożytnym. Udawanie się po radę do augurów, astrologów, magów czy wróżbitów nie było niczym zadziwiającym, choć w niektórych przypadkach mogło stanowić podstawę oskarżeń o działanie na szkodę państwa rzymskiego. Środowiska pogańskie nie akceptowały zasad i idei nowej religii chrześcijańskiej, głównie z powodu niezłożenia ofiar odpowiednim bóstwom i bardzo często, by pogrążyć chrześcijan, składano przeciwko nim świadectwa o uprawianie magii oraz nieczystych obrzędów ${ }^{1}$. Synkretyzm religijny w pozycji kulturowej Cesarstwa Rzymskiego miał swoje granice, które przekraczali właśnie chrześcijanie, będący aż do wydania edyktu mediolańskiego w 313 roku poddawani prześladowaniom o różnym stopniu natężenia ${ }^{2}$. Oskarżenia chrześcijan o magię mogły mieć jednak solidne podstawy - o tym, że wyznawcy Chrystusa wciąż czcili dawnych bogów, wierzyli w magię, odwiedzali astrologów i wróżbitów, pisał na początku III wieku Tertulian, który bardzo mocno krytykował takie zachowania³. Nie mogły one wszak dziwić. Bardzo ciężko było wyplenić część ugruntowanych tradycją zachowań u neofitów czy nawet starszych stażem chrześcijan. Dodatkowo od 313 roku możemy zaobserwować nowy problem - tzw. połowicznych nawróceń, kiedy to bardziej opłacało się zostać chrześcijaninem ze względu na fawory-

Por. A. Wypustek, Rola oskarżenia o magię i wróżbiarstwo w prześladowaniu chrześcijan na przetomie II i III w., „Vox Patrum” 17 (1997), z. 32-33, s. 56-60.

2 M. Banaszak, Historia Kościoła Katolickiego, Starożytność, Wydawnictwo Uniwersytetu Kardynała Stefana Wyszyńskiego, Warszawa 2005, t. 1, s. 147.

3 Por. Tertulianus, De idolatria VI-X, PL 1. 
zowanie tej grupy przez cesarzy ${ }^{4}$, szczególnie w życiu publicznym czy w armii ${ }^{5}$. Co więcej, niektórzy z bogatych pogan wykładali spore sumy pieniędzy za możliwość wyboru na urząd biskupi ${ }^{6}$, co świadczy o wysokiej pozycji późnoantycznych dostojników kościelnych. I tacy chrześcijanie skrycie, a czasami jawnie, wciąż oddawali cześć bożkom ${ }^{7}$, jednocześnie zapewne wchodząc swoim zachowaniem na terytoria praktyk magicznych.

Świat pogański i chrześcijański bowiem równie mocno zwalczały się, co przenikały wzajemnie ${ }^{8}$. Rok 313 stanowi tylko historyczną granicę w zmianie statusu prawnego chrześcijan. Proces chrystianizacji terenów Cesarstwa Rzymskiego był długi i żmudny. Wiara w czarownice, magię, siły demoniczne czy wróżby była silnie zakorzeniona, nie tylko wśród neofitów chrześcijańskich, ale nawet wewnątrz grup wiernych o ugruntowanych, wydawałoby się, poglądach.

Walka z reliktami praktyk pogańskich, obecnymi w społeczeństwie chrześcijańskim Cesarstwa Rzymskiego, zajmowała niemało czasu hierarchii kościelnej w IV i V wieku, kiedy to sobory i synody mogły obradować bez większych zakłóceń. Według moich badań, w samej części zachodniej Imperium, apostazje, czyli różnego rodzaju powroty do dawnych kultów, były drugim, najczęściej omawianym problemem na zgromadzeniach kościelnych, zaraz po kwestiach związanych z moralnością seksualną kleru i świeckich. Świadczy to o skali problemu oraz o tym, że nawet mimo ustanowienia chrześcijaństwa „religio licita” przez Teodozjusza Wielkiego wiele środowisk pozostawało opornymi w wyznawaniu nowej religii. W dokumentach kościelnych $\mathrm{w}$ interesującym nas okresie zaobserwować możemy troskę o jedność chrześcijan oraz wyraźnie zaznaczony element walki z wierzeniami pogańskimi, które niejako stanowiły części składowe misji Kościoła.

W niniejszym artykule zajmę się jednym z fragmentów kwestii związanych z apostazjami do pogaństwa, a mianowicie stosunkiem hierarchii kościelnej do praktyk magicznych. Owocem zainteresowania tym zagadnieniem na zgromadzeniach biskupich są oficjalne dokumenty, które te zgromadzenia wydały. Były i są one obowiązujące w całym Kościele, często uzupełniane nauką ojców Kościoła i ówczesnych pisarzy chrześcijańskich, oczywiście nie wszystkimi aspektami tych

4 Por. R. MacMullen, Christianizing the Roman Empire (A.D. 100-400), Courier Companies, New Haven - London 1984, s. 84-85; D. Kasprzak, Studium porównawcze myśli pasterskiej św. Piotra Chryzologa i Salwiana z Marsylii, Wydawnictwo Unum, Kraków 2008, s. 13.

5 J.P. Roth, Rzymska sztuka wojenna, Wydawnictwo „Książka i Wiedza”, Warszawa 2011, s. 255.

6 Por. I. Milewski, Depozycje i zsyłki biskupów w Cesarstwie Wschodniorzymskim (325-451), Wydawnictwo Uniwersytetu Gdańskiego, Gdańsk 2008, s. 15-16.

7 Por. D. Kasprzak, Kościół IV i V w. a połowiczne nawrócenia na chrześcijaństwo, w: Problemy duszpasterskie starożytnego Kościoła, red. J. Pałubicki, Wydawnictwo Katolickiego Uniwersytetu Lubelskiego, Lublin 2009, s. 161-183.

8 Szerzej na temat środowiska pogańskiego por. P. Chuvin, Ostatni poganie. Zanik wierzeń pogańskich $w$ cesarstwie rzymskim od panowania Konstantyna do Justyniana, Spółdzielnia Wydawnicza Czytelnik, Warszawa 2008. 
nauk, bo nie wszystkie włączono przecież do oficjalnego stanowiska Kościoła. Jako literaturę uzupełniającą włączyłem do tego studium dwa przeciwstawne z pozoru sobie zbiory praw. Pierwszy to zbiór przepisów ojców ze wschodniej części Imperium, opracowany przed Soborem Chalcedońskim w 451 roku, znany jako Canones Patrum Graecorum, poruszający szeroko rozumiane zagadnienia dyscyplinarne w pismach ojców wschodniej części Cesarstwa. Dodatkowo, aby ukazać burzliwe i żywe oblicze Kościoła późnoantycznego, na potrzeby artykułu włączyłem, jako źródło dokumentowe, Constitutiones Apostolorum, które powstały w drugiej połowie IV wieku i aspirowały do włączenia do oficjalnego kanonu kościelnego (autor powoływał się w nich na autorytet apostolski). Zarzuty stawiane temu źródłu, od początku jego pojawienia się w życiu Kościoła (głównie doktrynalne), nie mogą przesłonić nam tego, że stanowią cenny zapis i dowód intensywnego kształtowania się w różnych środowiskach późnoantycznych zasad kościelnych, a w niektórych Kościołach lokalnych część tych przepisów była i tak używana.

W tym krótkim przyczynku spróbuję dokonać odpowiedzi na pytanie, w jakim stopniu hierarchia kościelna IV i V wieku była zainteresowana sprawami praktyk magicznych wiernych oraz jakie były powody takiego, a nie innego natężenia tego zainteresowania. Celem jest także zwrócenie uwagi na zainteresowanie biskupów naglącymi problemami społecznymi epoki.

\section{A. ZGROMADZENIA BISKUPIE A PRAKTYKI MAGICZNE}

Pod pojęciem zgromadzeń biskupich rozumiemy zarówno synody (których w samym IV wieku odbyło się około $180^{\circ}$ ), czyli zgromadzenia lokalne jednej lub kilku prowincji, jak i sobory powszechne. Zarówno na synodach jak i soborach uchwalano przepisy, które nosiły nazwę kanonów i miały obowiązywać w Kościele. Kanon w ówczesnym pojęciu był pojedynczą decyzją danego zgromadzenia, w której zawarto zasady dotyczące chrześcijanina na każdym etapie jego życia ${ }^{10}$.

Wiele przepisów, które związane były z walką z apostazjami, wydane zostało przez pierwszy hiszpański synod, który obradował w Elwirze (dzisiejsza Grenada) w 306 roku $^{11}$. Nie może dziwić pojawiający się tam obraz negatywnego nastawienia biskupów do świata pogańskiego i wszelkich reliktów z nim związanych.

9 J. Woch, Biskup Rzymu wobec problemów kościołów wschodnich przy końcu IV w., „Vox Patrum” 24 (2004), t. 46-47, s. 245.

10 Por. J. Assmann, Pamięć kulturowa. Pismo, zapamiętywanie i tożsamość polityczna w cywilizacjach starożytnych, Wydawnictwa Uniwersytetu Warszawskiego, Warszawa 2008, s. 126.

11 Datacja synodu pozostaje niepewna, jednak raczej odbył się on w początku IV w. Por. V. de Clercq, Samuel Laeuchli, Power and Sexuality: The Emergence of Canon Law at the Synod of 
Na tym synodzie poruszono także bezpośrednio kwestię praktyk magicznych. W treści kanonu szóstego, który jest dla naszych rozważań nader interesujący, czytamy że komunii z Kościołem, nawet na łożu śmierci, nie otrzyma taki człowiek, który za pomocą zaklęcia (do którego potrzebne są czynności bałwochwalcze) zabije drugiego ${ }^{12}$. Takie przestępstwo było bardzo trudne do wykrycia, chociaż czasami zapewne wystarczał zwykły zbieg okoliczności, żeby je udowodnić. Przypuszczalnie można było takie zaklęcie rzucić samemu, prosząc właściwe bóstwa o pomoc. Wydaje się, że znacznie jednak powszechniejsze było zakupienie takich zaklęć u astrologów lub wróżbitów, których można było znaleźć w prawie każdej rzymskiej osadzie ${ }^{13}$.

Oprócz negatywnego podejścia do praktyk pogańskich, zauważamy tutaj pewnego rodzaju wiarę w zaklęcia, które w ostateczności doprowadzają do śmierci człowieka. Jest to tok myślenia, dość charakterystyczny dla Kościoła w interesującym nas okresie, albowiem bałwochwalstwo związane jest tu bezpośrednio z czarami, które prowadzą do złego uczynku, więc czary w tym kontekście służą szatanowi. I taki pogląd był przez Kościół aprobowany. Nie możemy też zapominać, że pogaństwo wciąż pozostawało silnym przeciwnikiem dla rozwijającej się prężnie nowej religii.

Kolejnym zgromadzeniem biskupim, gdzie zajęto się praktykami magicznymi, był synod w kapadockiej Ancyrze w 314 roku. Nakładano tam pokutę pięciu lat (trzy lata wśród leżących krzyżem i dwa lata modlitwy bez udziału w Komunii) dla tych, którzy udali się po radę do czarownika lub wróżbity ${ }^{14}$. Powody takich decyzji mogły być różne, są wśród nich na pewno też pozostałości praktyk pogańskich wśród chrześcijan. Z treści przepisu dowiadujemy się, że czarownicy byli zapraszani do domów, aby tam odczyniać swoje uroki. Dość surowa kara dla chrześcijan przyłapanych na takiej działalności wskazuje, że poważnie traktowano sprawy związane z kręgami pogańskimi. Możemy także wysnuć hipotezę, że praktyki magiczne były dość popularne, skoro na dwóch, dość odległych od siebie terytorialnie synodach, w mniej więcej tym samym czasie poruszono tę problematykę.

O tym, że uprawianie magii przez chrześcijan może być niebezpieczne, niechaj świadczy sprawa heretyków Pryscyliana i Istancjusza, nad którą obradował synod

Elvira (review), „Vigiliae Christianae” 29/1 (1975), s. 76; J. F. Ubina, Le councile d'Elvire et l'espirit du paganisme, „Dialogues d'histoire ancienne” 19/1 (1993), s. 309-318.

12 Can. 6, synod w Elwirze 306 r., w: Acta Synodalia ab anno 50 ad annum 381, compositio et elaboratio A. Baron, H. Pietras, SCL I, s. 51. Por. treść kanonu: „Si quis vero maleficio interficiat alterum, eo quod sine idololatria perficere scelus non potuit, nec in finem impertiendam esse illi communionem".

13 Por. A.G. Hamman, Życie codzienne w Afryce Pótnocnej w czasach św. Augustyna, Instytut Wydawniczy Pax, Warszawa 1989, s. 197-202.

14 Can. 24, synod w Ancyrze 314 r., w: SCL I, s. 68. 
w Burdigali (dzisiejsze Bordeaux) między 384 a 385 rokiem ${ }^{15}$. Jak przekazuje nam Sulpicjusz Sewer, Pryscylian, jako heretyk, został skazany na śmierć właśnie z powodu niejasnych praktyk magicznych i niemoralnego życia ${ }^{16}$. Dokładnie nie wiemy, jaką rolę odegrało to oskarżenie w całości procesu Pryscyliana. Jako że w sprawę zamieszany był, ogłoszony sam przez siebie cesarzem Maksym, któremu zależało na poparciu hierarchii kościelnej, to możemy domniemywać, że Pryscylian został skazany nie tylko ze względu na uprawianie magii. Takie oskarżenie o magię, co uwidoczniliśmy już we wprowadzeniu, służyło jako swoista broń przeciwko przeciwnikom czy to politycznym, czy religijnym.

W Seleucji-Ktezyfonie, gdzie perscy biskupi zebrali się w 424 roku, by podjąć decyzję o oddzieleniu się od Kościoła imperialnego ${ }^{17}$, ludzie zajmujący się magią (magowie) zostają tylko wspomniani, jako członkowie wysokiej grupy społecznej związanej z zoroastrianami, którzy prowadzili rozmowy z biskupami na tematy wierzeń i powrotu niektórych praktyk pogańskich ${ }^{18}$. Magowie ci byli jednak bardziej kapłanami-celebransami, aniżeli ludźmi, którzy rzucali zaklęcia.

Synod irlandzki, który miał miejsce między 456 a 465 rokiem, podobnie jak zgromadzenie w Elwirze, był pierwszym dla swoich terenów, a jego najsłynniejszym uczestnikiem był najprawdopodobniej biskup Patryk, ogłoszony później świętym $^{19}$. Poruszono na nim dwie kwestie związane z praktykami magicznymi. Synod ten zorganizowany został głównie w celu usprawnienia chrystianizacji pośród opornego i silnie pogańskiego społeczeństwa irlandzkiego ${ }^{20}$. Oficjalny czas chrystianizacji Irlandii (raczej niepełnej, co pokazują przykłady innych terenów europejskich), to lata 90 . V wieku, około 30 lat po śmierci biskupa Patryka ${ }^{21}$.

Pierwszy synod nowo przybyłej religii z oczywistych względów nie zasądzał nadto surowych kar za przewinienia, żeby nie zniechęcać neofitów, a jednocześnie odpowiednio ich upominać. Tylko rok pokuty otrzymywali ci, którzy uczęszczali do wróżbity, by poznać czekającą ich przyszłość, zaś po jej odprawieniu mieli przyjść do kapłana ze świadkami i otrzymywali rozgrzeszenie ${ }^{22}$. Naturalnym

15 Por. Sulpicius Severus, Chronicorum libri II, 49-50, CSEL 1.

16 Tamże II, 51.

17 Por. S.H. Moffet, A History of Christianity in Asia, vol. 1: Beginnigs to 1500, Orbis Books, New York 1998, s. 161-163.

18 Por. Synod w Seleucji-Ktezyfonie w 424 r., [45], w: Acta Synodalia ab anno 381 ad annum 431, compositio et elaboratio A. Baron, H. Pietras, SCL IV, Wydawnictwo WAM, Kraków 2010, s. 286; por. także S.H. Moffet, dz. cyt., s. 106-115.

19 Por. T.Ó. Fiaich, Początki chrześcijaństwa (V i VI wiek), w: Historia Irlandii, red. T.W. Moody, F.X. Martin, Zysk i S-ka, Poznań 1998, s. 65-70.

20 Por. E. Curtis, A History of Ireland. From Earliest Times to 1922, Routledge, London - New York 2002, s. 5-8.

21 Por. B.Ó. hEithir, Historia Irlandii, Wiedza Powszechna, Warszawa 2000, s. 11-12.

22 Can. 14, synod w Irlandii 456-465 r., w: Acta Synodalia ab anno 431 ad annum 504, compositio et elaboratio A. Baron, H. Pietras, SCL VI, Wydawnictwo WAM, Kraków 2011, s. 190. Por. treść 
wydaje się być, że w silnie pogańskiej Irlandii nowe obyczaje religijne były nadzwyczaj niełatwe do wprowadzenia. Jeżeli zaś zostało to poruszone na synodzie, oznaczało, że stanowiło dość powszechny problem społeczny.

Anatema kościelna po irlandzkim synodzie groziła również tym, którzy wierzyli w magiczne stwory, zwane strzygami, które miały rzekomo zamieszkiwać lustra oraz tym, którzy głosili takie poglądy - w obu przypadkach pokutę miał zasądzić kapłan (w kanonie nie wspomina się o tym szczegółowo), a winni tym praktykom powinni odwołać to, o czym głosili - inaczej nie mogli powrócić na łono Kościoła ${ }^{23}$. Czarownica przebywająca w lustrze, biskupia „striga”, pochodzi najprawdopodobniej od demona kobiecego zwanego „strix” (1. mn. „striges”), co oznaczało także puszczyka albo sowęę . Pojawiać się też miała pod postacią drapieżnego ptaka, który pił krew i jadł wnętrzności dzieci25. Uznaje się, że to „striges” były protoplastami słowiańskich strzyg ${ }^{26}$. „Striga” zamieszkująca lustro, które pełniło ważną rolę $\mathrm{w}$ praktykach magicznych ${ }^{27}$ była jednym $\mathrm{z}$ demonów pogańskich, w których wiarę zwalczać próbowała hierarchia kościelna. Co ciekawe, w dokumentach synodów w interesującym nas okresie, jest to jedyne odniesienie do zjawiska, które można by interpretować jako folklorystyczne i jedyny fragment, gdzie poza przykładami biblijnymi możemy przeczytać o potworze z krwi i kości oraz o jego miejscu pobytu. Biskupi jednak z takimi wierzeniami musieli walczyć.

Jeden z kanonów synodu, odbywającego się pomiędzy 461 a 491 rokiem, tym razem w galijskim Veneti (dzisiejsze Vannes), dotyczył specyficznego rodzaju praktyk magicznych, którym trudnili się niektórzy duchowni, a mianowicie „sortes sanctorum". Praktyka ta polegała na losowym otwieraniu Pisma Świętego i na tej podstawie przepowiadaniu przyszłości. Z zapisów pozostawionych przez biskupów możemy stwierdzić, że dotyczyło to tylko duchownych, którym groziło w przypadku przyłapania wyłączenie z Kościoła ${ }^{28}$. Nie wiemy, jakie sankcje gro-

kanonu: „Christianus qui [...] ad aruspicem meaverit, per singula crimina annum poenitentiae agat; impleto, cum testibus veniat, anno poenitantiae, et postea resolvetur a sacerdote".

${ }^{23}$ Can. 16, synod w Irlandii 456-465 r., w: SCL VI, s. 191. Por. treść kanonu: „Christianus qui crediderit esse lamiam in speculo, quae interpretatur striga, anathematizandus, quicunque super amiam, famam istam imposuerit; nec ante in ecclesiam recipiendus, quam ut idem criminis, quo fecie, sua iterum voce revocet, et sic poenitentiam cum omnia diligenta agat".

24 Por. Strzyga, w: Bogowie, demony, herosi. Leksykon, red. Z. Pasek, Wydawnictwo Znak, Kraków 1996, s. 452; P. Grimel, Słownik mitologii greckiej i rzymskiej, Zakład Narodowy im. Ossolińskich, Wrocław - Warszawa - Kraków 1997, s. 327.

25 J. Strzelczyk, Mity, podania i wierzenia dawnych Stowian, Rebis, Poznań 2007, s. 194.

26 Por. P. Baranowski, W kręgu upiorów i wilkołaków, Wydawnictwo Łódzkie, Łódź 1981, s. 9-11, 50; L. Pełka, Polska demonologia ludowa, Iskry, Warszawa 1987, s. 170-171.

27 Por. S. Melchior-Bonnet, Narzędzie magii. Historia luster i zwierciadet, Bellona, Warszawa 2007, s. 104-114.

${ }^{28}$ Can. 16, synod w Veneti 461-491 r., w: SCL VI, s. 239. Por. treść i tytuł kanonu: „XVI. De auguriis et sortibus sanctorum. /Ac ne id fortasse videatur omissum, quod maxime fidem catholicae religionis infestat, quod aliquanti clerici student auguriis et sub nominae fictae religionis, quas 
ziły wiernym w przypadku udowodnionego korzystania z usług kapłana-wróżbity. Nie zostają wspomniane, więc dopuszczamy możliwość, że żadne, ponieważ to od kapłana, który miał być przewodnikiem w wierze wymagało się odpowiedniego przygotowania - ludzie mogli korzystać nieświadomie z takich „usług”, ponieważ mogły one być dla nich częścią oficjalnego stanowiska Kościoła. Widzimy ponadto poprzez treść przepisu, że praktyki magiczne były trudne do zwalczenia, a co więcej, zajmowali się nimi nawet duchowni. Oczywiście nie wszyscy duchowni byli prawi i silnie wierzący. Zdarzali się wśród nich oszuści, pijacy, rozpustnicy oraz poganie, którzy dość swobodnie adaptowali się do nowo obowiązujących zasad $^{29}$, a poza tym prężnie rozwijające się chrześcijaństwo otwierało wiele możliwych dróg kariery.

Na synodzie galijskim, miejsce obrad pozostaje nieznane, pomiędzy 475 a 485 rokiem, w tzw. Statuta Ecclesiae powtórzono zakaz zajmowania się wróżbami i zaklęciami pod karą wyłączenia ze wspólnoty kościelnej ${ }^{30}$. Mimo podejmowanych prób walki z praktykami magicznymi, późnoantyczne społeczeństwo chrześcijańskie Cesarstwa wciąż zajmowało się wróżbami i zaklęciami, o czym świadczy ponawianie zakazów przez hierarchię kościelną.

\section{B. CANONES PATRUM GRAECORUM A PRAKTYKI MAGICZNE}

Wśród ojców Greckich ${ }^{31}$, którzy znaleźli swoje miejsce w spisie praw kościelnych, tylko trzech porusza temat magii. Są to Atanazy ${ }^{32}$, Bazyli Wielki oraz Grzegorz z Nyssy.

Atanazy przestrzega duchownych, żeby nie celebrowali wspólnie mszy św. $\mathrm{z}$ astrologami, czarodziejami i wróżbitami, ponieważ nie okazują oni należnego szacunku Bogu. Za takie działanie kapłanowi groziła degradacja do grona kate-

sanctorum sortes vocant, divinationis scientiam profitentur, aut quarumcumque scripturarum inspectione futura promittunt: hoc quicumque clericus detectus fuerit vel consulere vel docere, ab ecclesia habeatur extraneus".

29 J. Pałucki, Nawrócenia w IV w.. Motywy i reperkusje społeczne, „Vox Patrum” 17 (1997), z. 32-33, s. 192-193.

30 Can. 83, synod w Galii 475-485 r., w: SCL VI, s. 269. Por. treść kanonu: „Auguriis, vel incantantionibus servientem a conventu separandum [...]".

31 Szerzej na temat utrzymywania się praktyk wróżb (szczególnie z obserwacji ptaków) we wschodniej części Cesarstwa Rzymskiego. Por. I. Milewski, Oıonomanteia w wybranych relacjach późnoantycznych greckich autorów chrześcijańskich, „Przegląd Nauk Historycznych” XIV/2 (2015), s. 209-220.

32 Treść kanonów jest w języku arabskim, na który została przetłumaczona i przepisana ok. XI w., sama zaś treść kanonów jest znacznie wcześniejsza. Ewa Wipszycka datuje ich pochodzenie na przełom IV i V w. Por. E. Wipszycka, Études sur le Christianisme dans l'Égypte de l'antiquité tardive, Institutum Patristicum Augustinianum, Roma 1996, s. 205. 
chumenów ${ }^{33}$. Jak widzimy, ludzie parający się magią występowali w każdym zakątku Cesarstwa w interesującym nas czasie, co więcej, musieli posiadać też dość wysoką pozycję, skoro byli zapraszani do udziału w liturgii i to w takim charakterze.

Następna rada Atanazego również skierowana jest do duchownych i kandydatów do kapłaństwa. Nie wolno im przebywać w towarzystwie astrologów, czarodziejów, jasnowidzów i zaklinaczy, a tym bardziej słuchać ich rad ${ }^{34}$. Jeżeli takie przewinienie zostało potwierdzone przez trzech świadków, karą dla takich duchownym był zakaz udzielania Eucharystii przez trzy lata ${ }^{35}$. Mamy tutaj potwierdzenie oraz uzupełnienie wcześniej omawianego przepisu, a także dowód na żywe interakcje między światem pogańskim a chrześcijańskim w środowisku najprawdopodobniej egipskim.

Według Atanazego czytanie książek o magii także było poważnym wykroczeniem. Dziecko kapłana, które by się czegoś takiego dopuszczało, miało być ekskomunikowane, zaś jego ojciec, dopóki prawnie nie uwolni dziecka spod swojej władzy, miał być odsunięty od służby kapłańskiej ${ }^{36}$. Książki o magii musiały być zatem w miarę dostępne, ponadto duchowny, którego dziecko jawnie czytałoby owe dzieła, raczej tracił autorytet w społeczności chrześcijańskiej, nie dziwi zatem jego zawieszenie w służbie kapłańskiej do momentu „emancipatio”.

W zbiorze kanonów Bazylego Wielkiego także trzy dotyczą praktyk magicznych. Osoba przyrządzająca magiczne napoje lub wprost trudniąca się czarodziejstwem miała odbyć pokutę taką jak dla zabójców ${ }^{37}$, a zatem wynoszącą pomiędzy 10 a 20 lat bez udziału w Eucharystii ${ }^{38}$. Identyczną karę otrzymywali utrzymujący bliższe stosunki z osobami, które parały się wróżbiarstwem ${ }^{39}$. Ci zaś, którzy tylko udawali się po radę po sporządzenie napoju lub zapraszali wróżbitę do domu, by tam czynił swoje czary, otrzymywali karę sześciu lat wyłączenia ze wspólnoty kościelnej ${ }^{40}$. Przepisy stworzone przez Bazylego dają nam potwierdzenie wcześniejszych ustaleń. Zajmowanie się praktykami magicznymi przez chrześcijan było dość często spowodowane nie do końca dobrze rozumianą wiarą, a także działalnością różnego autoramentu magów, którzy sprzedawali swoje usługi. Ludność, która pozostawała pogańska, nie musiała przecież, jak chrześcijanie, rezygnować ze swoich praktyk magicznych.

33 Athanasius (versio arabica), Can. 25, w: Canones Patrum Graecorum (greaca et polonica), Athanasii et Hipolytii (arabica et polonica), compositio et elaboratio A. Baron, H. Pietras, SCL III, s. $144-145$.

34 Tenże, Can. 41, w: SCL III, s. 148.

35 Tamże.

36 Tenże, Can. 71, w: SCL III, s. 157.

37 Basilius Magnus, Can. 65, w: SCL III, s. 55.

38 Tenże, Can. 56-57, w: SCL III, s. 53.

39 Tenże, Can. 72, w: SCL III, s. 56.

40 Tenże, Can. 83, w: SCL III, s. 59. 
Grzegorz z Nyssy w swoich kanonach przybliża natomiast praktykę udzielania kar kościelnych za udawanie się po rady do czarowników lub wróżbitów. Wyższa konieczność, taka jak chociażby choroba czy zła sytuacja życiowa, dla Grzegorza stanowi okoliczność łagodzącą przy udzielaniu kary i tacy ludzie mogą powrócić na łono Kościoła po odbyciu pokuty przewidzianej za rozpustę ${ }^{41}$ (zależnie od prowincji, najczęściej kilka lat bez łączności z Kościołem, Grzegorz ten czas zaś ocenia na dziewięć lat ${ }^{42}$ ). Tacy zaś, którzy czynili to zupełnie świadomie, mogli dostąpić komunii dopiero na łożu śmierci, jeśliby taka była ich wola ${ }^{43}$.

\section{CONSTITUTIONES APOSTOLORUM A PRAKTYKI MAGICZNE}

Constitutiones Apostolorum naprawdę niewiele miejsca poświęcają magii. Pierwszy znajdowany ustęp jest lakoniczny i dotyczy tylko zakazu uprawiania czarów i magii, bez podawania kar czy środków zaradczych ${ }^{44}$. Podobnie w tej samej księdze mamy powtórzenie zakazu o uprawianiu wróżbiarstwa, czynieniu zaklęć oraz wróżeniu, również brakuje sankcji, autor powołuje się jedynie na autorytet Pisma Świętego przeciwko praktykom magicznym ${ }^{45}$.

W Lex canonica sanctorum apostolorum, tradycyjnie przypisywanym do Constitutiones Apostolorum, odnajdujemy jeden zapis mówiący o tym, że kto płaci wróżbitkom za wróżby oraz kto od nich bierze „pisma”, ma podlegać karze ekskomuniki ${ }^{46}$. Z kolei w Poena pro lapsis ss. apostolorum dostajemy potwierdzenie kanonu 65. Bazylego Wielkiego, gdzie autor, bądź autorzy, dla czynnego chrześcijańskiego praktyka magii przewidują karę 20 lat wyłączenia ze wspólnoty ${ }^{47}$.

Pomimo ubogości treściowej Constitutiones Apostolorum oraz powiązanych z nimi tekstów jesteśmy w stanie dostrzec, że nawet w środowisku autora (autorów) tworzącego owe źródła, kwestie związane z praktykami magicznymi pojawiają się i są brane pod dyskusję - a zatem musiały też istnieć w ówczesnym społeczeństwie chrześcijańskim.

41 Gregorius Nyssenus, Can. 3, w: SCL III, s. 79.

42 Tenże, Can. 4, w: SCL III, s. 79-80.

43 Tenże, Can. 3, w: SCL III, s. 79.

44 Const. Apost. VII, 3, 1, w: Constitutiones apostolorum et Canones Pamphilii ex synodo apostolico Antiochemo, Lex canonica sanctorum apostolurym, Poene pro lapsis sanctorum apostolorum, Euchologion Serapionism, compositio et elaboratio A. Baron, H. Pietras, Synodi et Collectiones Legum vol. II [dalej: SCL II], Wydawnictwo WAM, Kraków 2007, s. 177.

45 Tamże VII, 6, 1-2, w: SCL II, s. 178-179.

46 Lex canonica sanctorum apostolorum 17, w: SCL II, s. 297.

47 Poena pro lapsis ss. apostolorum 9, w: SCL II, s. 298. 


\section{PODSUMOWANIE}

Problem praktykowania magii przez chrześcijan istniał w późnoantycznym Kościele, o czym świadczyć może podejmowana z tym walka na zgromadzeniach biskupich. Efektem tych zmagań były przepisy prawa kościelnego wydawane przez różne zgromadzenia biskupie. Problem praktyk magicznych jest jednak tylko niewielką częścią składową całego ówczesnego problemu, jakim były apostazje do pogaństwa oraz wszelkie związane z tym kwestie. W IV i V wieku chrześcijaństwo rozwijało się nader dynamicznie, pragnąc kontrolować wszelkie przejawy życia ludzkiego i próbując wyeliminować jedynego przeciwnika, którym były nie tak skonsolidowane środowiska pogańskie. Dużą pomoc hierarchia kościelna uzyskała w tej walce od cesarzy, którzy od lat 80 . IV wieku z coraz większą przychylnością spoglądali na chrześcijan, wydając kolejne ustawy wymierzone w pogan ${ }^{48}$. Problem powrotów do kultów pogańskich pozostawał jednak duży i na niektórych terenach dawnego Cesarstwa Rzymskiego zwalczony ostatecznie został dopiero w średniowieczu.

Jeżeli zaś chodzi o konkretne przejawy praktyk magicznych, które wyłaniają się nam ze źródeł dokumentowych Kościoła późnoantycznego, to nie mamy ich dużo. Nie są one też precyzyjne. W większości mowa jest o zakazie uprawiania magii, wróżenia, uczęszczania do wróżbitów czy przyrządzania różnych zaklęć oraz napojów. Za wszystkie te wykroczenia groziły oczywiście odpowiednie kary, najczęściej czasowego wyłączenia ze wspólnoty z Kościołem. W skrajnych przypadkach oskarżenie o magię mogło być podstawą do wydania wyroku śmierci przez sądy cywilne. Najbardziej precyzyjne zapisy, które choć trochę mogą ubarwić nasz wizerunek ówczesnego społeczeństwa, pochodzą z synodów w Veneti o losach świętych czynionych przez duchowieństwo oraz z synodu w Irlandii, gdzie zabrania się wierzyć w strzygi zamieszkujące lustra. Dlaczego te przepisy są tak ogólne? Najbardziej prawdopodobna odpowiedź, jaka się nasuwa, to taka, że wówczas każdy z ludzi wiedział po co idzie do astrologa, czarodzieja, maga czy wróżbity oraz czego tam może oczekiwać (dla wielu zapewne były to liczne wizyty) i nie było sensu wyszczególniać tego w kolejnych kanonach.

W konkluzji nasuwa się także jeszcze inne pytanie. Dlaczego, mimo tak wielkiego bogactwa świata wierzeń pogańskich, tak niewiele miejsca hierarchia kościelna poświęciła praktykom magicznym? Wydawać się może, że związane jest to z bardzo dużym natężeniem przepisów wydawanych przeciwko apostazjom do pogaństwa. Bardzo często praktyki pogańskie w tych kanonach traktowane są ogólnie. Zapewne w cały zestaw apostazji wpisywały się także praktyki magiczne

48 Por. M. Ożóg, Kościót starożytny wobec światyń oraz posagów bóstw, Wydawnictwo WAM, Kraków 2009, s. 75-126. 
(bez konkretnego wspominania o nich w treściach przepisu), nie widziano jednak potrzeby częstego powtarzania i przypominania o tym wiernym. Hierarchowie więcej uwagi poświęcali szerzej pojmowanej walce z pogaństwem, zasądzaniu kar i wymyślaniu środków zaradczych.

Możemy założyć, że problem praktyk magicznych dotyczył całego obszaru Imperium, ponieważ podobne zapisy znajdujemy w Elwirze (Hiszpania), Ancyrze (Azja Mniejsza), Irlandii czy Galii. Dodatkowo kanony Atanazego potwierdzają istnienie praktyk magicznych w Egipcie, a Bazylego i Grzegorza z Nyssy znów przenoszą nas do Azji Mniejszej. Również Constitutiones Apostolorum potwierdzają, że w interesującym nas okresie takie praktyki istniały. Na pewno też szybko nie ziściło się marzenie św. Augustyna, który uważał, że wszelkie pogańskie praktyki powinny być zakazane i surowo karane ${ }^{49}$ (ustawodawstwo cesarskie w końcu IV w. nie poradziło sobie z tym problemem).

\section{Bibliografia}

Acta Synodalia ab anno 50 ad annum 381, compositio et elaboratio A. Baron, H. Pietras, Synodi et Collectiones Legum vol. I, Wydawnictwo WAM, Kraków 2006.

Acta Synodalia ab anno 381 ad annum 431, compositio et elaboratio A. Baron, H. Pietras, Synodi et Collectiones Legum vol. IV, Wydawnictwo WAM, Kraków 2010.

Acta Synodalia ab anno 431 ad annum 504, compositio et elaboratio A. Baron, H. Pietras, Synodi et Collectiones Legum vol. VI, Wydawnictwo WAM, Kraków 2011.

Assmann J., Pamięć kulturowa. Pismo, zapamiętywanie i tożsamość polityczna w cywilizacjach starożytnych, Wydawnictwa Uniwersytetu Warszawskiego, Warszawa 2008.

Augustinus, De doctrina Christiana, CSEL 80.

Banaszak M., Historia Kościoła Katolickiego, Starożytność, Wydawnictwo Uniwersytetu Kardynała Stefana Wyszyńskiego, Warszawa 2005, t. 1.

Baranowski P., W kręgu upiorów i wilkołaków, Wydawnictwo Łódzkie, Łódź 1981.

Bogowie, demony, herosi. Leksykon, red. Z. Pasek, Wydawnictwo Znak, Kraków 1996.

Canones Patrum Graecorum (greaca et polonica), Athanasii et Hipolytii (arabica et polonica), compositio et elaboratio A. Baron, H. Pietras, Synodi et Collectiones Legum vol. III, Wydawnictwo WAM, Kraków 2009.

49 Augustinus, De doctrina Christiana II, 36, CSEL 80. 
Chuvin P., Ostatni poganie. Zanik wierzeń pogańskich w cesarstwie rzymskim od panowania Konstantyna do Justyniana, Spółdzielnia Wydawnicza Czytelnik, Warszawa 2008.

Constitutiones apostolorum et Canones Pamphilii ex synodo apostolico Antiochemo, Lex canonica sanctorum apostolurym, Poene pro lapsis sanctorum apostolorum, Euchologion Serapionis, compositio et elaboratio A. Baron, H. Pietras, Synodi et Collectiones Legum vol. II, Wydawnictwo WAM, Kraków 2007.

Curtis E., A History of Ireland. From Earliest Times to 1922, Routledge, London - New York 2002.

de Clercq V., Samuel Laeuchli, Power and Sexuality: The Emergence of Canon Law at the Synod of Elvira (review), „Vigiliae Christianae” 29/1 (1975), s. 75-77.

Grimel P., Słownik mitologii greckiej i rzymskiej, Zakład Narodowy im. Ossolińskich, Wrocław - Warszawa - Kraków 1997.

Hamman A.G., Życie codzienne w Afryce Pótnocnej w czasach św. Augustyna, Instytut Wydawniczy PAX, Warszawa 1989.

hEithir B.Ó., Historia Irlandii, Wiedza Powszechna, Warszawa 2000.

Historia Irlandii, red. T.W. Moody, F.X. Martin, Zysk i S-ka, Poznań 1998.

Kasprzak D., Studium porównawcze myśli pasterskiej św. Piotra Chryzologa i Salwiana z Marsylii, Wydawnictwo Unum, Kraków 2008.

MacMullen R., Christianizing the Roman Empire (A.D. 100-400), Courier Companies, New Haven - London 1984.

Melchior-Bonnet S., Narzędzie magii. Historia luster i zwierciadet, Bellona, Warszawa 2007.

Milewski I., Depozycje i zsytki biskupów w Cesarstwie Wschodniorzymskim (325-451), Wydawnictwo Uniwersytetu Gdańskiego, Gdańsk 2008.

Milewski I., Olonomanteía w wybranych relacjach póżnoantycznych greckich autorów chrześcijańskich, „Przegląd Nauk Historycznych” XIV/2 (2015), s. 209-220.

Pałucki J., Nawrócenia w IV w.. Motywy i reperkusje społeczne, „Vox Patrum” 17 (1997), z. 32-33, s. 187-198.

Problemy duszpasterskie starożytnego Kościoła, red. J. Pałubicki, Wydawnictwo Katolickiego Uniwersytetu Lubelskiego, Lublin 2009.

Moffet S.H., A History of Christianity in Asia, vol. 1: Beginnigs to 1500, Orbis Books, New York 1998.

Ożóg M., Kościót starożytny wobec światyń oraz posagów bóstw, Wydawnictwo WAM, Kraków 2009.

Pełka L., Polska demonologia ludowa, Iskry, Warszawa 1987.

Roth J.P., Rzymska sztuka wojenna, Wydawnictwo „Książka i Wiedza”, Warszawa 2011.

Strzelczyk J., Mity, podania i wierzenia dawnych Stowian, Rebis, Poznań 2007. Sulpicius Severus, Chronicorum libri, CSEL 1. 
Tertulianus, De idolatria, PL 1.

Ubina J.F., Le councile d'Elvire et l'espirit du paganisme, „Dialogues d'histoire ancienne" 19/1 (1993), s. 309-318.

Wipszycka E., Études sur le Christianisme dans l'Égypte de l'antiquité tardive, Institutum Patristicum Augustinianum, Roma 1996.

Woch J., Biskup Rzymu wobec problemów Kościołów Wschodnich przy końcu $I V$ w., „Vox Patrum” 24 (2004), t. 46-47, s. 231-248.

Wypustek A., Rola oskarżenia o magię $i$ wróżbiarstwo w prześladowaniu chrześcijan na przełomie II i III w., „Vox Patrum” 17 (1997), z. 32-33, s. 45-60.

\section{Streszczenie}

W artykule zaprezentowałem kilka uwag dotyczących praktyk magicznych chrześcijan, które odnaleźć można w późnoantycznych (IV i V w.) kościelnych tekstach normatywnych, takich jak akta synodów, Canones Patrum Greacorum czy Constitutiones Apostolorum. Problem praktyk magicznych uprawianych przez chrześcijan dotyczył całego obszaru Cesarstwa Rzymskiego i związany był głównie z pozostałościami (w niektórych prowincjach zachodnich bardzo silnymi) kultów pogańskich, a także z tym, że nie wszyscy mieszkańcy Imperium przyjęli religię chrześcijańską. W źródłach dokumentowych Kościoła niewiele znajdziemy zapisów dotyczących interesującego nas zagadnienia. Głównie odnajdujemy zakazy uprawiania magii, wróżenia, uczęszczania do wróżbitów, przyrządzania zaklęć oraz napojów. Za wszystkie te wykroczenia groziły oczywiście odpowiednie kary, najczęściej czasowego wyłączenia ze wspólnoty z Kościołem.

Słowa kluczowe: magia, wróżbiarstwo, chrześcijaństwo antyczne, późnoantyczne społeczeństwo rzymskie, synody, Kościót starożytny, Canones Patrum Greacorum, Constitutiones Apostolorum

\footnotetext{
A Few Remarks on the Magical Practices of Christians in the Late Antiquity Church Normative Texts
}

\section{Summary}

In this article I presented a few remarks on the magical practices performed by Christians which can be found in the late antiquity (IV and V century) ecclesiastical normative texts such as the files of synods, Canones Patrum Greacorum or Constitutiones Apostolorum. This problem concerned the entire area of the Roman Empire and was associated mainly with the remains of the pagan cult (in some Western provinces it remained very strong) and also with the fact that not all the population of the empire adopted the Christian religion. There are scarce ecclesial 
documentary sources regarding the magical practices in question. These texts usually ban any usage of magic or fortune-telling, attending diviners and preparing spells or potions. The culprits of such offenses would, of course, incur appropriate penalties, often in the form of the temporary exclusion from the community of the Church. Why are these rules so general? The most probable answer is that back then everyone knew why he or she was going to an astrologer, a wizard, a magician or a fortune-teller and what they could expect (often there was a series of such appointments) and there was no point detailing it in the corresponding canons. Quite possibly the whole issue of apostasy was also included in the chapters regarding the magical practices (without specific mentioning it in the text of the precepts) but there was no need to remind Christians about it so frequently. The hierarchs were rather focused on such problems as the struggle against paganism.

Keywords: magic, fortune-telling, ancient Christianity, late antiquity Roman society, synods, ancient church, Canones Patrum Greacorum, Constitutiones Apostolorum 